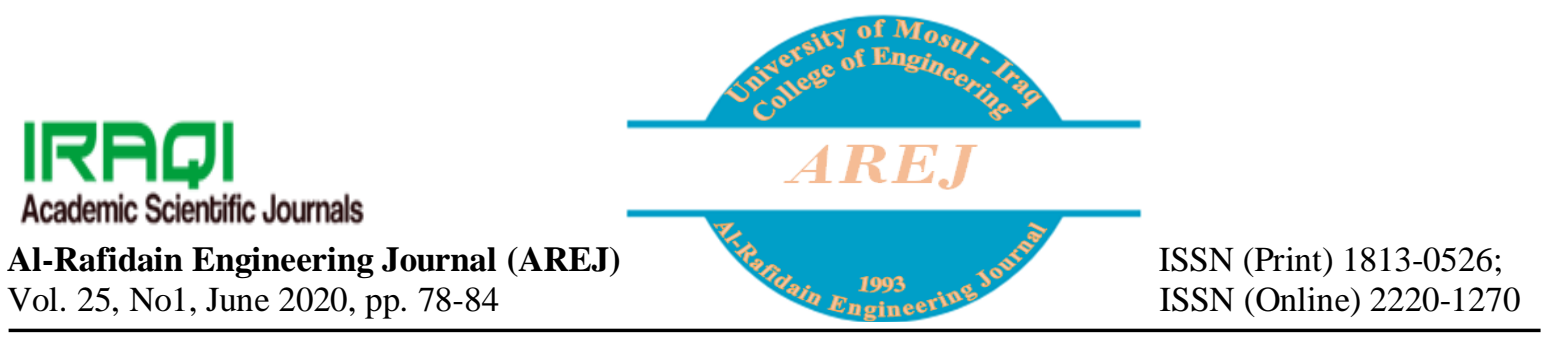

\title{
Eichhornia and Ceratophyllum Monitoring System Based on IoT for Iraqi's Irrigation projects
}

\author{
Nassr Myasar Abdullah \\ nassr.comp.eng@gmail.com \\ Rabee M. Hagem \\ rabeehagem@uomosul.edu.iq \\ Computer Engineering Department, Collage of Engineering, University of Mosul
}

Received: 3/4/2020

Accepted: 6/6/2020

\begin{abstract}
Advancments in technologies can help solve many problems. Internet of Things (IoT), a recent technology, can be employed to tackle the problems with irrigation systems in Iraq that suffer from agricultural pests. Such pests are known as emergence of bushes and weeds, such as (Eichhornia and Ceratophyllum), that spread in waterways, stream and river back, estuaries, irrigation channels, gates, and systems.They basically impedethe flow of water and affect the fucntion of pumps, gates and sprinklers, and can evencause them to stop working. Agricultural pests, in addition, consume huge amounts of water that Iraq critically needs, especially in the years of drought and lack of rain.The present study shows the deisgn of a system, for monitoring and controlling the agricultural pests, that uses IoT Wi-Fi Photon board with a GUI (Graphical User Interface) which is supported with an early notification system. The reasons for the growth of these pests and their spread are discussed in this study. Moreover, there are two methods suggested to limit the emergence of the Ceratophyllum plant and detect of the Eichhornia from an early stage. The results showed that the proposed system is feasible.
\end{abstract}

\section{Keywords:}

IOT,Irrigation Projects, Pests, Eichhornia, Ceratophyllum, GUI.

https://rengj.mosuljournals.com

Email: alrafidain_engjournall@uomosul.edu.iq

\section{INTRODUCTION}

Iraq has built many irrigation projects on the rivers and tributaries that flow through it.These projects irrigate large areas of agricultural land used to produce crops such as wheat, barley, rice, dates, citrus and many other vegetables and fruits. These products constitute an important and large part of the country's economy, especially after the low oil prices and the emergence of the urgent need to find alternatives to support the economy of the country.The majority of these irrigation projects suffer from aquatic weeds especially Eichhornia and Ceratophyllum.

In[1] and [2], Eichhornia ,Water hyacinth, Eichhornia crassipes or locally known as Zahret Al-Nile (Nile flower) in Iraq, violet a large floating violet or purple flower that create an attractive landscape. It's original habitat in the tropics of South America .
Eichhornia consumes large quanities of water daily for its fast growth. According to [3] each plant consumes about 1.3-2.7L/day.It can aslo present a threat to aquatic life and irrigation systems. It impedes navigation in the rivers and can potentially displace the indigenous water plants leaving a negative impact on the environment.It is very fast growing and reproductive plant.

Iraq has established The Department of Nile Flower and Waterweed Treatment. The Department is affiliated to the Ministry of Water Resources and is responsible to control and solve the problem of these pests. According to this department, the budget for removing this plant is five billion Iraqi dinars per year.

Some official managers in the Department of Waterand the Iraqi Minister of Water Resources describe the Nile flower asa green terroristdisease 
that invads IRAQ. They encourage the elimination of Eichhornia and stress the importance of saving the marshes and rivers from it.

The plant ranks first among the most dangerous bushes in the world.If the plant spreads or settls in a region, the area is considered to have a water distaster as the plant can cause significant economic lossesand water reservoirscausing great losses in quantities of water through transpiration: evaporation of water from the surfaces of the plant's leaves accounts for a loss of 1.5 liters of water per day per flower.It also impedes the flow of water in irrigation channels.It may lead to the emergence of a dense cover or even cause a blockage and disruption of water pumps. Moreover, it forms a shelter for insects that transmit pathogens that affect humans and animals.

Ceratophyllum is the other aquatic pest that focused on in the presnt study.According to [4] and [5]Ceratophyllumisa submerged perennial plant without roots, whichoften grows upin the base of the stem buried in sediments, attached to the rivers, lake, and irrigation channelsbottomby modified leaves. Hornwort can obstruct the phytoplankton growth in shallow water, which contributes to the stabilization of the macrophytedominatedstate characterized by clear water.

According to a case study in BabelGovernorate [6], thebudget devoted to the removal,locally known as(sombolan or shombolan), in various mechanical and human methods, from urinals, streams and irrigation canals is 1.25 million Iraqi Dinars $/ \mathrm{km}$. This plant reduces the area of the flowing section in cannals, drains and streams, and also leads to an unfair distribution of water in these irrigated sections. This is in addition to the increase in water losses due to transpiration processes - evaporation of the plant. It constitutes a good environment for the appearance of abundance of harmful insects that can affect human and animal health.

Notwithstanding, the implementation of mechanical methods used to remove these pests is both difficlut and not cost effective. These methods consume lots of fuel which, in turn, lead to large amounts of toxic emissions alarming environmental concerns specfically in Iraq which is a developing country. According to [7] the developing countries are at the forefront of the countries that are heavily polluted.

According to what has been mentioned, we learn that these agricultural/aquatic pests constitute a real threat to agriculture, irrigation projects, and even human beings and
environment.According to [8]mentioned that the IoT and sensors network make everything especially agriculture and pests control smarter and easier than before. The Internet of Things can solve many of these problems, perhaps before they occur in the first place orfrom an early stage.

In paper [9]the IoT is thekey to precision agriculture. It turns things from being manual and static to automatic and dynamic.

In addition to this introduction, this paper contains four other sections. Section 2 presents the problem statement. The proposed methodology is fully explained in section 3. The obtained results and their corresponding discussions and conclusion are included in section 4. Finally, section 5 is the future work.

\section{PROBLEM STATEMENT}

Through many field trips done by the authors, we have noticed the presence of these two pests largely in Iraqi irrigation projects,as seen infigs.(1a, 1b) which represent the Ceratophyllum in one of irrigation channelsand the use of a dredger to remove it.Figs. $(2 \mathrm{a}, 2 \mathrm{~b})$ show the infection with the Eichhornia in some projects in Mosul. The specialists working at the site unanimously emphasized that these two banners exhaust efforts to maintain unbostructed flow of water in the channels and that their removal demands huge funds. IoT smart design contributes to to the elimination or early detection of the plant. or early detection totreat them early.

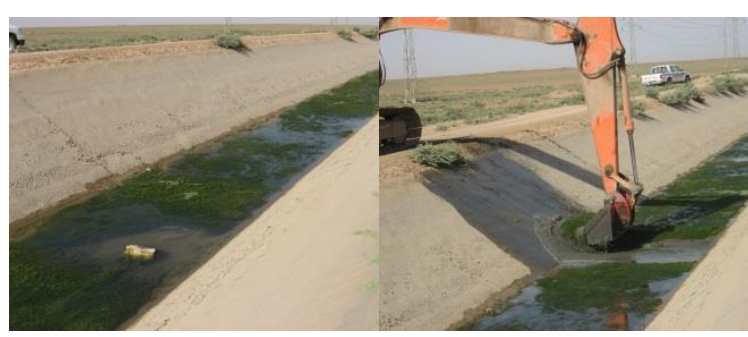

Fig.1a: Ceratophyllum Fig.1b: Ceratophyllum on one of irrigation removal Using a channel mechanical dredger

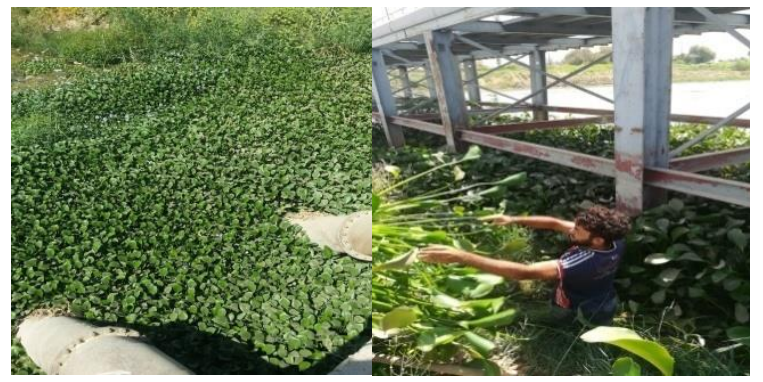

Fig. 2 a,b :Infection with the Eichhornia in the some projects in Mosul 


\section{PROPOSED DESIGN METHODOLOGY}

We notedfrom[10] and theliterature mentioned in refrences [4 and 5]that the Ceratophyllum plant is very difficult to eliminate because of many obstacles inherent in the process of removing itby mechanical and manual methods beside the high removal cost. This plant has seeds that have the ability to spread and remain in a state of lethargy for up to 15 years. It has the ability to regrow again if appropriate conditions areavailable. Therefore, the present study resonates with the importance of "prevention is better than cure". Based on the previous researchers and sources, the most important reason for the emergence of this plant, especially in the irrigation canals, drains and irrigation streams, is the little amount or shallow water depththat leads to lightreaching the bottom of these facilities, and thus the Ceratophyllum grows.

As indicated in [6], the second important reason for this plant to appear and grow is the stagnation of water and its non-flowing, which leads to less water turbidity and increased water transparency; consequently, the sun reaches sediments at the bottom of the irrigation facilities and the plant grows.Refrences [11]\&[12] were able to maintain a certain level of water inside a tank using the ultrasonicsensor and an Arduino microcontroller board.

Therefore, we used the ultrasonic sensor installed at the top of the irrigation channels, streams and spacers as shown in fig. 3 .

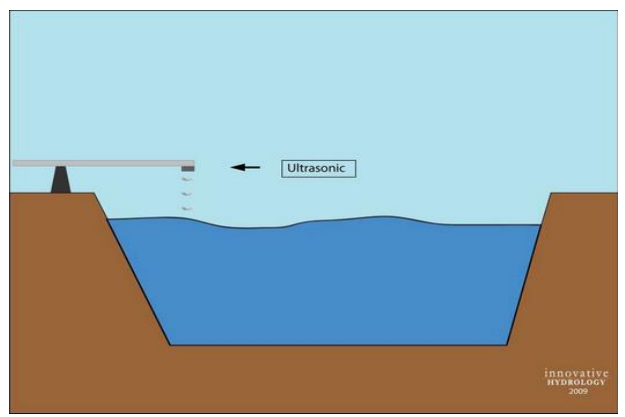

Fig.3: Ultrasonic sensor installed above

This is linked with other sensors of the National Smart Irrigation Project (soil moisture, temperature, smoke and motion sensors) that we are working on as shown in fig.4. and through the Particle Cloud to the Blynk program on the mobile of the person responsible for closing and opening the irrigation gate to maintain a certain water level that prevents this plant from appearing.

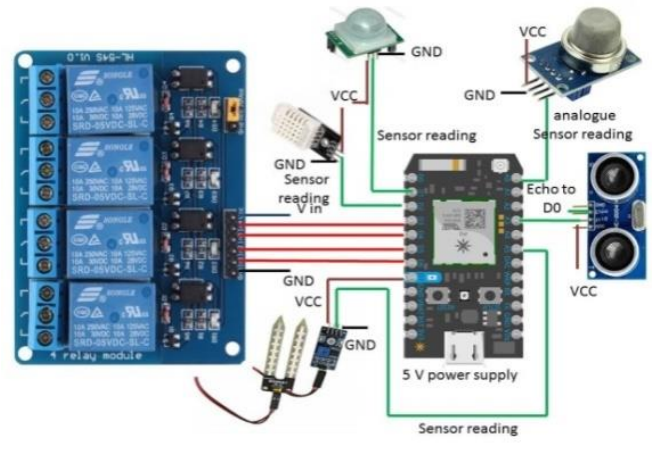

Fig. 4: circuit diagram for smart irrigation system

As the name implies, ultrasonic sensors measure the distance using ultrasound; one of the sensor heads emits ultrasound $(\mathrm{T})$ while the second head receives the reflected wave(R) from the target as shown in figure (5).

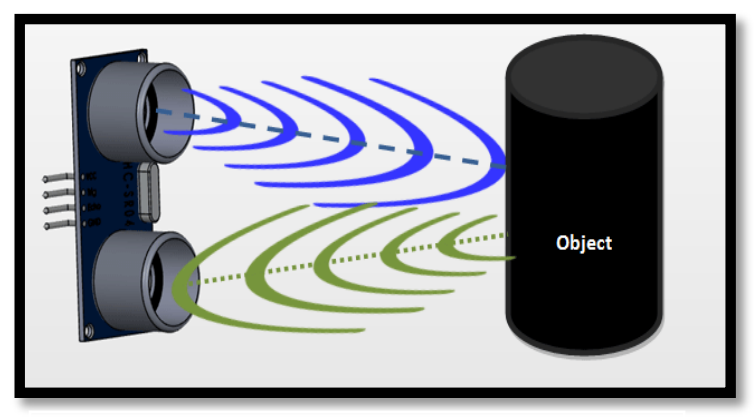

Fig.5: Ultrasonic sensor operation method

Ultrasonic sensors measure the distance to a target by measuring the time between the transmitter and the receiver. To connect this sensor, we need a $5 \mathrm{~V}$ powerwhich is necessary for the sensor to work properly. When connecting the sensor to a $3.3 \mathrm{~V}$ voltage source, it would give incorrect results.

The Trig pin must be connected to an analog port on the development board, while the Echo pin must be connected to a digital port for the same board to obtain accurate results. It measures dimensions ranging from 1-160 inch.On the other hand, because of the vast extant of lands, the water irrigation projects, the engineers informed us, feed many channels, some of which yield no benefit.However, the ultrasonic sensor installed on these channels indicates the same reading for a long time without change. This is something that should draw the attention of officials for the purpose of heading to that channel and blocking water to maintain a level of water in the rest of the other channels that irrigate the lands and to reduce the process of evaporation of water which reducethe likelihood of the emergence of aCeratophyllumplant. 
On the other hand, we note that, according to the mentionedresearch above $[1,2,3]$ and $[13]$, Eichhornia dramatically spreads and nothing can prevent or limit its growth when appropriate conditions such as the relatively high temperature and water are available.

Eichhornia has a beautiful appearance and lack of knowledge about its potential threats to water and irrigation projects have concealed the fact that it is a harmful pest. Moreover, people purchase it as an ornamental plant in parts of Iraq.

After initializing and contacting the router to obtain the internet, the program sends a request to obtain the necessary weather information for the work of the National Smart Irrigation Project.After that the system begins by reading the values of all sensors attached to the development board and displaying them on the graphical interface and Blynk application, with respect to ultrasonic sensors. If the reading isgreater than the threshold limit (this means that the water level in the channel is low) a warning message is sent to the person's email to reset the irrigation gate. Fig. 6 shows the block diagram of the proposed system.

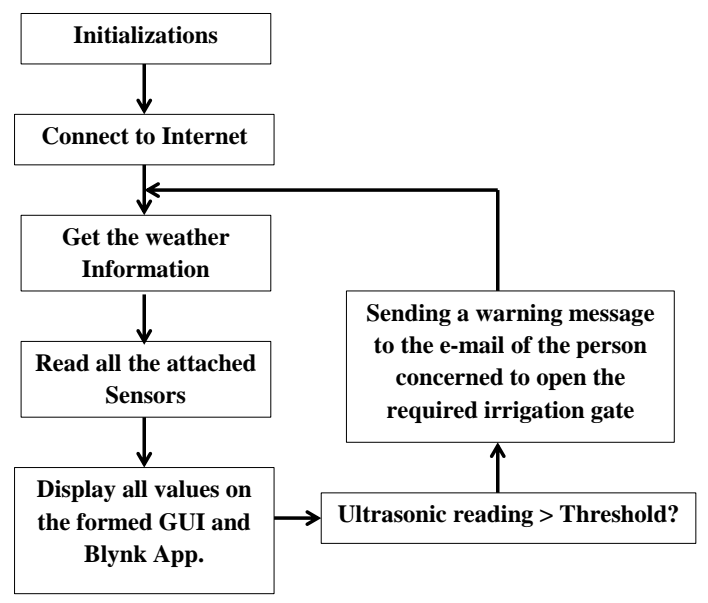

Fig.6: Block diagram of the proposed system

We noticed that the danger of this plant lies with the amazing speed of its reproduction, as mentioned by [14]. One plant of the Eichhornia multiplies to become 100 plants andoccupies a swab 20 times the area it occupied at the beginning after four weeks. So this plant should be detected early as shown in Figure 7. It turns out the extent of the weeds in some projects due to the late detection and treatment.

We suggested using drone planes to patrol along rivers in Iraq during the period of growth and reproduction of this plant (during the summer).
Aaccording to [8], the UAVs Unmanned Aerial Vehicle (drones) with GPS are used in the agricultural sector to cover vast and large areas of land. UAVs provide "eye in the sky" because of the high resolution cameras that give a great picture.UAVs are being used in a range of agricultural applications, including planting, crop healthmonitoring,plant

counting,agriculturephotography, spraying and many other variable rate applications.After being equipped with automation and GPS capabilities, they are ready to take the agriculture sector to a further modernized level.

Refrences[15]\&[16] ensure that drones can detect pests, weeds and other dieseaes that infects the plants because of the great development taking place in the drons technology.They mentioned that everyone who used the drone in agriculture has achieved tremendous benefits. Research [17] used drones with HD pro camera,node cu 8266 and employed ANNfor weeds and pets detection. The system is used to carry out image processing and monitor the fields. Theresults were great in the detection of diseases, weeds and the estimation of the correct quantities of pesticides and the fertilizers needed to obtain crops of good quality and quantity.

Reserch [18]mentioned wonderful capabilities of the drones with image processing capabilities.

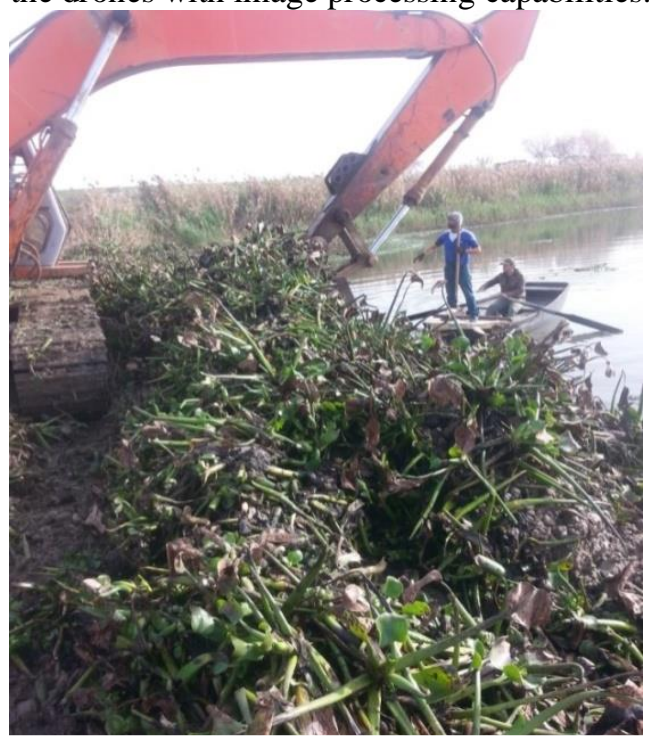

Fig.7: Eichhornia extent, large size of flowers, leaves and stems are clearly obvious.

processing and extracting the necessary information to make specific decisions.

Therefore, we suggested using the dronesespecially in the hot months of the year when these plants increase at a huge rate- in monitoring the emergence of these harmful plants and eliminating them before they spread. The features 
of drones by reaching remote areas that cannot be easily accessedby humans. Moreover, their high speed and accuracy in covering large areas in a short time make them perfect for early pest detection.

\section{RESULTS AND DISCUSSIONS WITH CONCLUSIONS}

The use of the Internet of things cannot be neglected in controlling and treatment of weeds and harmful weeds, so with the use of ultrasonic sensors and linked over irrigation canals, to the mobile phone ofthe person responsible for opening and closing irrigation gatecan maintain a certain water level that reduces the appearance of the Ceratophyllum plant.

Fig. (8) shows an image for a GUI that is designed by the authorsof the National Smart Irrigation project. It shows the reading of several sensors. However, this study has focused on the reading of the water distance/depth received from the ultrasonic sensor installed on the top of the irrigation canals.

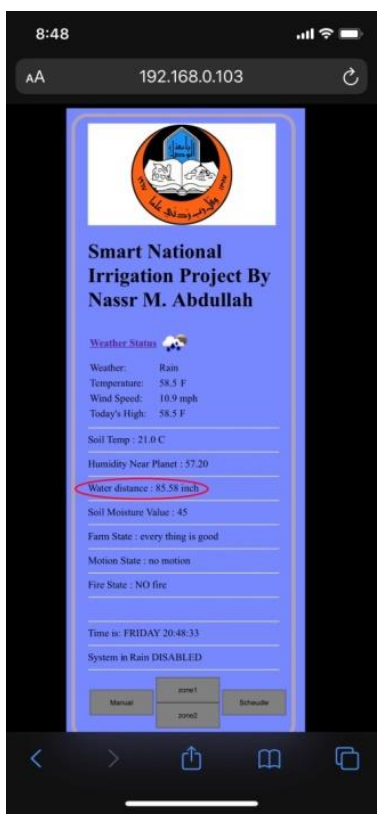

Fig.8: GUI designed by the authors for the national smart irrigation system focusing on the ultrasonic sensor readings

As shown, the reading refers to 85.5inch, and if we know that the depth of the irrigation canal is approximately 120inches, then this means that the height of the water at present is approximately $34.5 \mathrm{inch}$.

Another example is shown in Figure 9, where it shows another reading for a different ultrasonic sensor published ona
blynkapplication.Thatcan be used on a mobile phone making it accessible to anyone anytime anywhere. The results showed that the system is feasible.

The present research find that there is, surprisingly, a ban on the use of UAVs with built in cameras to help detect Nile flower plants as it requires obtaining formal and fundamental approvals from the security authorities in Iraq. It is difficult to obtain them, especially in light of the current security conditions and challenges the country is going through, they are prohibited from selling in the local markets, and there is also a ban on their purchase from the World Wide Web.

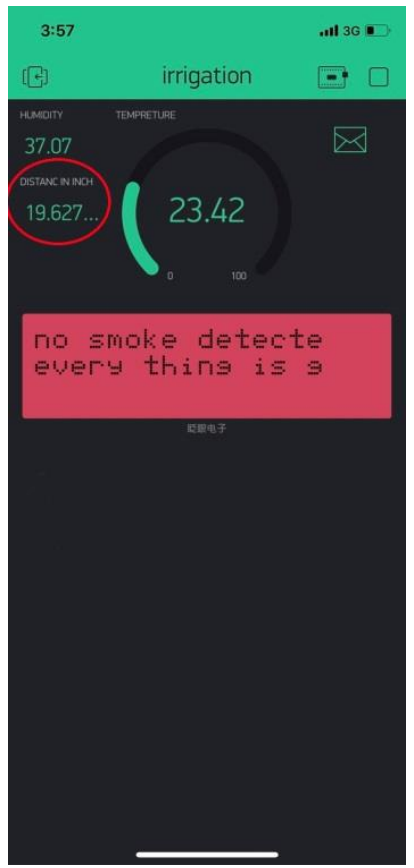

Fig.9: Ultra Sonic sensor reading in Blynk App on mobile Phone focusing on the ultrasonic reading

Through many researches that dealt with this topic and some of which are mentioned above, we expect to obtain impressive results in the field of early detection of the Eichhornia by using UAVs. The system that is able to determine whether a plant is infected with a specific disease, through a shape or effect on its leaves, widefinitely be able to determine the whereabouts of this harmful plant.

\section{FUTURE WORKS}

There need to be attempts to obtain official and fundamental approvals from the competent security authorities in the country to import or purchase UAVs. Moreover, for practical detection of the Eichhornia plant, early detecting sysetms 
need to be impelemented and integrated with an efficient image processing system. This feature can be added to the National Smart Irrigation Project (NSIP) that the authors working on to be a complete system.

\section{ACKNOLEDGMENT}

The authors of this paper want to thanks the engineers of Nineveh Directorate of Maintenance, Irrigation and Drainages Projects for providing some useful information which enhance this paper. Also, for giving official permissions and help in visiting some work sites in Mosul irrigation projects and taking pictures that were used in this research.

\section{REFERENCES}

[1] D. Simpson and H. Sanderson, "434 . EICHHORNIA CRASSIPES : Pontederiaceae Source: Curtis, S Botanical Magazine, Vol . 19 , No . 1 ( February 2002 ), pp . 28-34 Published by: Wiley Stable URL: https://www.jstor.org/stable/45065515," vol. 19, no. 1, pp. 28-34, 2020.

[2] S. Rezania et al., "Nutrient uptake and wastewater purification with Water Hyacinth and its effect on plant growth in batch system," J. Environ. Treat. Tech., vol. 1, no. 2, pp. 81-85, 2013.

[3] Dr. Ahmed Jassim Mohammed AlShammari and Dr. Hamza Kazem AlZubaidi, "Laboratory Studying of the Fecundity Schedules for Neochetina bruchi ( Hustache ) [ Coleoptera: Curculionidae ] under the Lab . conditions and the Possibilities of its Use Against Waterhyacinth in Iraq . Neochetina bruchi," Karbala Univ. / Second Sci. Conf. Coll. Sci., pp. 10-16, 2014.

[4] M. Mjelde and B. A. Faafeng, "Ceratophyllum demersum hampers phytoplankton development in some small Norwegian lakes over a wide range of phosphorus concentrations and geographical latitude," Freshw. Biol., vol. 37, no. 2, pp. 355-365, 1997.

[5] D. E. \& E. I. Elisabeth M. Gross, "Allelopathic activity of Ceratophyllum demersum L. and Najas marina ssp. intermedia (Wolfgang) Casper," Hydrobiologia, pp. 583-589, 2003.

[6] R. S. Mahdi, "The economic feasibility study to remove the shamlan plant from the water in a mechanical way. A case study in Babil Governorate," Babylon Univ. J., vol. 19, no. 4, p. 10, 2011.

[7] H. R. and E. O.-O. Max Roser, "World Population Growth," Our World Data, no. Published online https://ourworldindata.org/worldpopulation-growth, 2020.

[8] M. Ayaz, M. Ammad-Uddin, Z. Sharif, A. Mansour, and E.-H. M. Aggoune, "Internet-of-Things (IoT)-Based Smart Agriculture: Toward Making the Fields Talk," IEEE Access, vol. 7, pp. 129551129583, 2019.

[9] U. Shafi, R. Mumtaz, J. García-Nieto, S. A. Hassan, S. A. R. Zaidi, and N. Iqbal, "Precision agriculture techniques and practices: From considerations to applications," Sensors (Switzerland), vol. 19, no. 17, pp. 1-25, 2019.

[10] F. M. Hassan, "The Distribution of Ceratophyllum demersum L . in Relation to nvironmental Factors in Restored AlMashb marsh , Hor Al-Hammar , Southern Iraq .," vol. 7, no. 2, pp. 137149, 2012.

[11] R. Sunmonu, S. Aduramo, O. S Abdulai, and E. A Agboola, "Development of an Ultrasonic Sensor Based Water Level Indicator With Pump Switching Technique," J. Electr. Eng., no. June, 2018.

[12] K. S. Varun, K. A. Kumar, V. R. Chowdary, and C. S. K. Raju, "Water Level Management Using Ultrasonic Sensor(Automation)," Int. J. Comput. Sci. Eng., vol. 6, no. 6, pp. 799-804, 2018.

[13] M. A. H. Al-hadeethi and B. Mohamed, "Anatomical Features of (Eichhornia Crassipes (Mart.) Solms) Growing in Iraq," no. October, 2018.

[14] A. H. . . A.-W. $1 *$ and A. M. S. 2 1, "Study The Seed Germination in Different Time of Planting on Propagation and Growth of Eichhornia crassipes (Mart) Solms in Northern Iraq.," Journal, Tikrit Vol, Agric. Sci., vol. 18, pp. 1-8, 2018.

[15] M. Reinecke and T. Prinsloo, "The influence of drone monitoring on crop health and harvest size," 2017 1st Int. Conf. Next Gener. Comput. Appl. NextComp 2017, pp. 5-10, 2017.

[16] F. H. I. Filho, W. B. Heldens, Z. Kong, and E. S. De Lange, "Drones: Innovative Technology for Use in Precision Pest Management Drones: Innovative Technology for Use in Precision Pest 
Management," no. December, 2019.

[17] R. L. Hari Shankar, A. K. Veeraraghavan, Uvais, K. Sivaraman, and S. Shreyas Ramachandran, "Application of UAV for pest, weeds and disease detection using open computer vision," Proc. Int. Conf. Smart Syst. Inven. Technol. ICSSIT 2018, no. December, pp. 287-292, 2018.

[18] S. Karim, Y. Zhang, A. A. Laghari, and M. R. Asif, "Image processing based proposed drone for detecting and controlling street crimes," Int. Conf. Commun. Technol. Proceedings, ICCT, vol. 2017-Octob, no. October, pp. 17251730, 2018.

[19] M. Salhaoui, A. Guerrero-González, M.
Arioua, F. J. Ortiz, A. El Oualkadi, and C. L. Torregrosa, "Smart industrial iot monitoring and control system based on UAV and cloud computing applied to a concrete plant," Sensors (Switzerland), vol. 19, no. $15,2019$.

\title{
نظام مراقبة زهرة النيل ونبات الثمبلان بالاعتماد على انترنيت الاشياء في مشاريع العراق الإروائية بالأية
}

\author{
ربيع موفق حاجم \\ rabeehagem@uomosul.edu.iq \\ نصر ميسر عبدالله \\ nassr.comp.eng@gmail.com \\ جامعة الموصل ـ كلية الهندسة ـ قسم هندسة الحاسوب
}

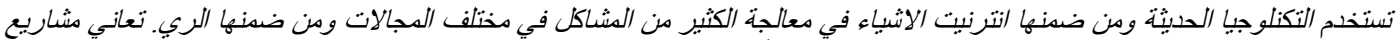

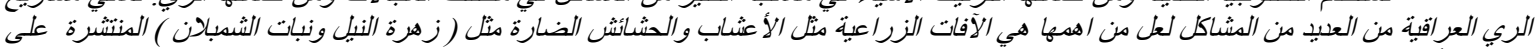

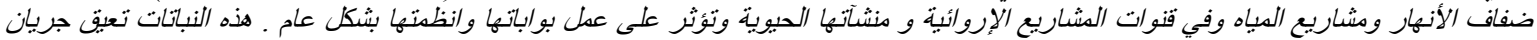

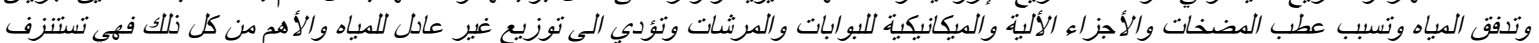

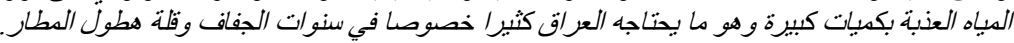

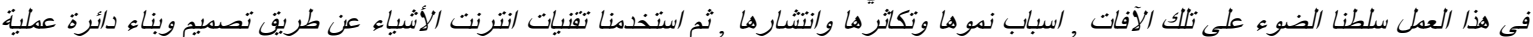

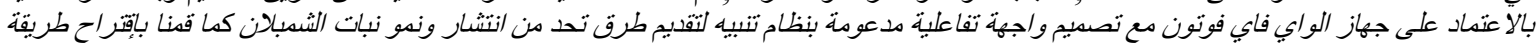
للكثف العبكر عن زهرة النيل . النتائج اظهرت ان هذا النظام فعال وبيكن استخدمه في مشاريع العراق الروائية.

الكلمات الدالهه :

تقنية انترنت الأشياء, مشاريع الري , الآفات الضارة , زهرة النبل ,نبات الثدبلان, الواجهة التفاعلية للمستخدم. 